Available online on 15.09.2021 at http://ujpr.org
Universal Journal of Pharmaceutical Research
An International Peer Reviewed Journal
Open access to Pharmaceutical research

\title{
EVALUATION OF ANTIBACTERIAL ACTIVITY OF SOME MEDICINAL PLANTS BY BIOAUTOGRAPHY

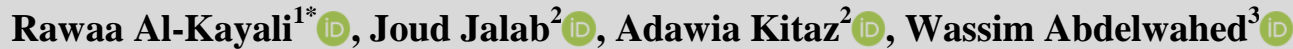 \\ ${ }^{1}$ Biochemistry and Microbiology Department, Faculty of Pharmacy, University of Aleppo, Syria. \\ ${ }^{2}$ Pharmacognosy Department, Faculty of Pharmacy, University of Aleppo, Syria. \\ ${ }^{3}$ Pharmaceutics and Pharmaceutical Technology Department- Faculty of Pharmacy, University of Aleppo, Syria.
}

\section{ABSTRACT}

Background Acacia cyanophylla is a medicinal plant of the Fabaceae family that is widely distributed in Australia and Asia, also it has many medicinal properties such as antibacterial and antioxidant activity. Thin layer chromatography (TLC) is wildly used in natural product extract analysis as a finger print.

Aim and objective: This study aimed to conducting a qualitative detection of the active compounds in Acacia cyanophylla, Phlomis syriaca and Scolymus hispanicus plants by thin layer chromatography (TLC) method and studying their antibacterial activity.

Methods: the qualitative detection of three plants was conducting using thin layer chromatography (TLC) method. Then, aqueous and ethanolic extracts of the aerial parts of the three plants were extracted using an Ultrasonic bath. The antibacterial activity on E. coli isolates for six extracts was evaluated using minimum inhibitory concentration (MIC) test. The active compounds that may be responsible for the antibacterial effect was isolated by direct bioautograph method.

Results: Performing Thin-layer chromatography TLC tests show that the three plant contain flavonoids, saponin, bitter principles and essential oils, and all extracts showed antibacterial activity on E. coli isolates, but the ethanolic extract of Acacia cyanophylla was the most effective as the MIC values ranged from 0.097 to $3.125 \mathrm{mg} / \mathrm{mL}$. Bioautography showed that Escherichia coli was inhibited by most of the separated flavonoids on the TLC plates where four inhibiting spots appeared in yellow color with Acacia cyanophylla and five spots with Scolymus hispanicus, while only one spot appeared with Phlomis syriaca.

Conclusion: Acacia cyanophylla extract has been considered as the best antibacterial properties among the selected plants due to the presence of flavonoids

Keywords: Acacia cyanophylla, antibacterial, bioautography, flavonoids, Phlomis syriaca, Scolymus hispanicus.

Article Info: Received 4 July 2021; Revised 7 August; Accepted 2 September, Available online 15 September 2021

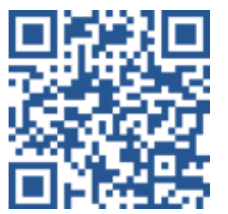

Cite this article-

Al-Kayali R, Jalab J, Kitaz A, Abdelwahed W. Evaluation of antibacterial activity of some medicinal plants by bioautography. Universal Journal of Pharmaceutical Research 2021; 6(4):42-49.

DOI: https://doi.org/10.22270/ujpr.v6i4.639

Address for Correspondence

Dr. Rawaa Al-Kayali, Biochemistry and Microbiology Department, Faculty of Pharmacy, University of Aleppo, Syria, Tel- +963947472305; E-mail: rawah67@hotmail.com

\section{INTRODUCTION}

The significance of medicinal plants cannot be overlooked. The natural products available either as pure compounds or as standard extracts, are considered the largest source for new drugs discoveries due to their content of various bioactive chemical compounds $^{1}$. Nowadays, the health system is facing great difficulties in the treatment of bacterial diseases due to the development of antibiotics bacterial resistant strains which causes high rates of morbidity and mortality ${ }^{2}$. A wide variety of phytochemicals have been demonstrated to be potential antibacterial agents, including terpenoids, essential oils, alkalis, lectins, polypeptides, phenols and polyphenols ${ }^{3}$. Many plant extracts have plentiful phenolic compounds that may display anti-bacterial activity in addition to their antioxidant activity. The mechanisms of the antibacterial effect of phenolic compounds have not been fully known alteration of the permeability of cell membranes, loss of functions within cells due to hydrogen binding of phenolic compounds to enzymes and modifying of cell wall stiffness with loss of integration have been documented ${ }^{3}$. The elevated lipophilic feature of phenolic compounds improves their antimicrobial activity. Flavonoids which are the base class of polypehols with general structure includes two phenyl rings (A and $\mathrm{B}$ ) and a heterocyclic ring $(\mathrm{C})$ may bind to soluble proteins found outside of cells and with the bacterial cell walls thus enhancing the 
formation of complexes. In addition, flavonoids may also act by inhibiting both energy metabolism and nucleic acids synthesis ${ }^{3,4}$. Thin layer chromatography (TLC) has been generally used in analysis of plant extracts for active components because many samples can be analyzed in one development. If required, the affirmation can be performed using an automated technique like gas chromatography- mass spectrometry (GC-MS) or liquid chromatography- mass spectrometer (LC-MS). However, TLC continues the first-choice method due to simplicity and economical. The singularity of TLC is that it can provide information about biological properties of the sample, for example, antioxidants and antimicrobial when combined with direct bioautography ${ }^{5}$. Bioautography is planar chromatographic analysis hyphenated with the biological detection method ${ }^{6}$, it is simple, economical, time-saving, do not require advanced equipment and more sensitive than any other methods ${ }^{7}$. Bioautography is efficacious technique for identifying a biologically active component with antibacterial activity from plant extracts ${ }^{1}$. There are three methods of bioautography; contact bioautography, direct bioautographic and overlay bioautography ${ }^{6}$. Direct Bioautography is the most widely applied of all bioautography methods ${ }^{7}$. The World Health Organization (WHO) has reported more than 21,000 plants which are utilized for many medicinal usesworldwide ${ }^{8}$ and a large number of medicinal plants have been observed as useful sources of natural antimicrobial compounds ${ }^{9}$. The genus Acacia belongs to the Fabaceae family and involve an enormous number of species (about 1500), forming it the largest genus within the previous family. It is widespread in Australia, Asia, Africa and the Americas $^{10}$. Acacia species have been reported to contain secondary metabolites including amines, alkaloids, fatty acids, amino acids, terpenes (including essential oils, diterpene and triterpene), hydrolyzed tannins, flavonoids, and condensed tannins ${ }^{11}$. Several studies have reported that $A$. cyanophylla has strong potential antimicrobial effects ${ }^{12}$. It also has important antioxidant and anti-acetylcholinesterase activity ${ }^{13}$. The genus Phlomis L. is one of the largest genera of the Lamiaceae family, with more than hindered species including herbs, shrubs. This genus is distributed in the northern temperate regions, especially in Europe and Asia $^{14}$ that possess anti-inflammatory, immunosuppressive, antioxidant and antimicrobial effects. Various classes of glycosides, consisting mainly of diterpenoids, iridiodes, phenylpropanoid, phenylthanoid, flavonoids essential oils have been identified $^{15}$. Scolymus hispanicus L. is a thistle-like plant in the family Asteraceae, a prickly perpetual herb with a circum-Mediterranean allocation which grows in Spain but it is scarce in the north of the country ${ }^{16}$. Although its leaf and root is usually used as a vegetable, it is also utilized in alternative medicine. $S$. hispanicus L. leaves stems and flowers are used as a "bitter" tonic to stimulate appetite ${ }^{17}$. It has depurative, diuretic, choleretic, digestive and lithiuretic effect ${ }^{16}$. The aerial parts contain bioactive compounds such as flavonoids, flavonoid glucosides and flavonol rutinosides ${ }^{18}$ and this plant is rich in dietary fiber, total phenolic compounds, and showed elevated antioxidant capacity ${ }^{17}$. Among which A. cyanophylla, P. syriaca and $S$. hispanicus are known to be indigenous in the flora of Syria. In particular, despite widespread of these plants, the literature contains few reports of antibacterial activity and chemical composition of these plants growing in Syria. This study aimed to identify the various phytoconstituents components in the crude extracts of $A$. cyanophylla, $P$. syriaca and $S$. hispanicus that are responsible for antibacterial activity.

\section{METHODS}

\section{Plant Material}

Fresh aerial parts (leaves, flowers and stems) of $A$. cyanophylla, $P$. syriaca and $S$. hispanicus were collected between March \April 2020 from different regions of northern Syria. The plant were authenticated by Dr Ahmad Jaddouh, an expert at Faculty of Agriculture - University of Aleppo, Syria. The plant sample were cleaned with distilled water and dried at normal room temperature for 15 days ${ }^{19,20}$. The dried sample were ground to powder with the domestic blender and kept in glass container until use. ${ }^{21}$

\section{Bacterial Strains}

Fifteen E. coli isolates that included in the study was obtained from patients with urinary tract infections at Aleppo University Hospital laboratory. Isolates were identified by Gram stain, their microscopically appearance and their growth on the differential media. Isolates are kept in the liquid nutrient medium with $30 \%$ glycerol, at $-20^{\circ} \mathrm{C}$ until use ${ }^{8}$.

\section{Plant Extraction}

Fine powder of three plants $(30 \mathrm{~g})$ was extracted with two different solvents (distilled water, ethanol 95\%) for one hour in an ultrasonic bath (POWERSONIC 405 (Hwashin Technology Co, Korea). The temperature was maintained at $50^{\circ} \mathrm{C}$. The plant: solvent ratio was 1:10 (w/v). The extract solutions were filtered through Whatman No. 1 filter papers, and the residual material was re-extracted twice using the same procedure. The combined extracts were evaporated to dryness in a rotary evaporator (Rotary evaporator, Heidolph Instruments, Germany) at $50^{\circ} \mathrm{C}$ and under reduced pressure to remove the solvent ${ }^{20}$. The obtained crude extracts were stored in dark glass bottles and refrigerated at $-4^{\circ} \mathrm{C}$ until use ${ }^{21}$.

\section{Antibacterial Susceptibility}

The antibiotic susceptibility of isolates was tested using disk diffusion method (Kirby Bauer) according to the Clinical and Laboratory Standards Institute (CLSI) guidelines $^{22}$ to eight antibiotics belonging to four main groups: Ampicillin and Sulbactum (10\10 $\mu \mathrm{g})$, Cefepime $(30 \mu \mathrm{g})$, Nalidixic acid $(30 \mu \mathrm{g})$, Ceftazidime (30 $\mu \mathrm{g})$, Cefpodoxime $(10 \mu \mathrm{g})$, Cifuroxim $(30 \mu \mathrm{g})$, Ceftriaxone $(30 \mu \mathrm{g})$ and Nitrofurantoin $(300 \mu \mathrm{g})$. (IVD Group, Benex Limitted, USA)

\section{Minimum Inhibitory Concentration (MIC) Test}

The antibacterial activity of the extracts was determined by establishing the minimum inhibitory concentration (MIC) using microdilution method. For this purpose, stock solutions of examined extracts and 
Mueller-Hinton broth were prepared. The stock solution of each extract was prepared by dissolving 200 $\mathrm{mg} / \mathrm{mL}$ of extract in dimethyl sulfoxide (DMSO). First, adding $50 \mu \mathrm{L}$ of Mueller- Hinton broth (MHB) and 50 $\mu \mathrm{L}$ of bacterial suspension at a concentration of 0.5 McFarland $\left(1.5 \times 10^{8} \mathrm{CFU} / \mathrm{mL}\right)$ to the first well as a negative control. Then, adding $50 \mu \mathrm{L}$ of the selected plant extract at the highest concentration to the second well and $50 \mu \mathrm{L}$ of bacterial suspension as a positive control. Second, $50 \mu \mathrm{L}$ of the selected plant extract at the highest concentration to the third well and it is diluted by adding $50 \mu \mathrm{L}$ of MHB, then $50 \mu \mathrm{L}$ are taken from the mixture for the fourth well and so on, the concentrations of tested extracts ranged between $(0.097$ to100) $\mathrm{mg} \backslash \mathrm{mL}$. Then $50 \mu \mathrm{L}$ of bacterial suspension are added for each wells. The microtiter plate was sealed with parafilm and incubated at $37^{\circ} \mathrm{C}$ for $24 \mathrm{~h}$. The MIC of each tested isolate was detected by adding $20 \mu \mathrm{L}$ of $0.2 \mathrm{mg} / \mathrm{mL}$ indicator dye; 2, 3, 5-triphenyltetrazolium chloride (TTC) into the microtiter plate wells and incubated for $30 \mathrm{~min}$ at $37^{\circ} \mathrm{C}$ and observed any color change to red color which indicates bacterial growth $^{2,23}$. TTC is colorless in the oxidized form and red in reduced form. The dehydrogenase enzyme of living bacteria reduces tetrazolium salt in the indicator into intensely pinkish-red formazan compound ${ }^{7}$. When the solutions color of microtiter plate wells remains unchanged, this indicates that the growth of bacteria is inhibited $^{2,7}$

Thin Layer Chromatography (TLC)

Three types of extracts were prepared:

Extract $_{1}$ : Powdered plant $(1 \mathrm{~g})$ is extracted by heating on a water bath for 15 min with $5 \mathrm{~mL}$ methanol then filtrated for detection of bitter principles and flavonoids.
Extract $_{2}$ : Powdered plant $(1 \mathrm{~g})$ is moistened with $1 \mathrm{~mL}$ of $10 \%$ ammonia solution, and then extracted by shaking for $15 \mathrm{~min}$ at $60^{\circ} \mathrm{C}$ with $5 \mathrm{~mL}$ methanol for inspection of alkaloids.

Extract $_{3}$ : A methanol extract was prepared as in extract 1 . After evaporation, $1 \mathrm{~mL}$ of filtrate was mixed with $0.5 \mathrm{~mL}$ water, followed by $3 \mathrm{~mL}$ butanol for detection of saponins

Extract : Powdered plant ( $1 \mathrm{~g})$ was extracted by heating under reflux for $15 \mathrm{~min}$ with $10 \mathrm{~mL}$ Dichloromethane. The filtrate was evaporated to dryness, and the residue was dissolved in $1 \mathrm{~mL}$ toluene for inspection of essential oils.

From each extract, $20 \mu \mathrm{L}$ of extract was applied to a TLC silica gel plate (60F254, $10 \mathrm{~cm} \mathrm{x} 10 \mathrm{~cm})$. Chromatography was conducted in one of these solvent systems:

1. Ethyl acetate-methanol-water (100: 13.5: 10): For the analysis of bitter principles, flavonoids, alkaloids and saponins.

2. Toluene-ethyl acetate (93: 7): For the analysis of essential oils.

Both solvents are permitted to pass a distance of $8 \mathrm{~cm}$. After inspection in UV- $254 \mathrm{~nm}$ and UV-365 nm, each chromatogram is analyzed for the presence of one of the groups of plant component by spraying with an suitable reagent such as:

1. Bornträger reagent $(10 \%$ ethanolic $\mathrm{KOH})$ : for detection anthraquinones.

2. Dragendorff reagent: for detection alkaloids.

3. Natural products-polyethyleneglycol reagent (NP/PEG): for detection flavonoids.

4. Vanillin-sulphuric acid reagent: for detection Bitter principles and saponins ${ }^{24}$.

Table 1: Susceptibility of $E$. coli isolates against studied antibiotics.

\begin{tabular}{|c|c|c|c|c|c|c|c|c|}
\hline $\begin{array}{l}\text { Isolates } \\
\text { number }\end{array}$ & $\begin{array}{c}\text { SAM } \\
10 / 10 \mu g\end{array}$ & $\begin{array}{c}\text { FEP } \\
30 \mu \mathrm{g}\end{array}$ & $\begin{array}{l}\text { NAL } \\
30 \mu g\end{array}$ & $\begin{array}{l}\text { CAZ } \\
30 \mu \mathrm{g}\end{array}$ & $\begin{array}{c}\text { CPD } \\
10 \mu \mathrm{g}\end{array}$ & $\begin{array}{l}\text { CXM } \\
30 \mu \mathrm{g}\end{array}$ & $\begin{array}{l}\text { CRO } \\
30 \mu g\end{array}$ & $\begin{array}{c}\text { NIF } \\
300 \mu \mathrm{g}\end{array}$ \\
\hline 1 & $\mathrm{~S}$ & $\mathrm{~S}$ & $\mathrm{R}$ & $\mathrm{R}$ & $\mathrm{R}$ & $\mathrm{R}$ & $\mathrm{R}$ & $S$ \\
\hline 2 & $S$ & $S$ & $\mathrm{R}$ & $S$ & S & $S$ & $S$ & $S$ \\
\hline 3 & $S$ & $S$ & $\mathrm{R}$ & $S$ & $\mathrm{R}$ & $\mathrm{R}$ & $\mathrm{R}$ & $S$ \\
\hline 4 & $S$ & $S$ & $\mathrm{R}$ & $S$ & $S$ & $S$ & $S$ & $\mathrm{~S}$ \\
\hline 5 & I & $\mathrm{R}$ & $\mathrm{R}$ & $\mathrm{R}$ & $\mathrm{R}$ & $\mathrm{R}$ & $\mathrm{R}$ & $S$ \\
\hline 6 & $S$ & $S$ & $\mathrm{R}$ & $S$ & $\mathrm{R}$ & $\mathrm{R}$ & $\mathrm{R}$ & $\mathrm{S}$ \\
\hline 7 & $S$ & $S$ & $\mathrm{R}$ & $\mathrm{R}$ & $\mathrm{R}$ & $\mathrm{R}$ & $\mathrm{R}$ & $S$ \\
\hline 8 & $\mathrm{R}$ & $\mathrm{R}$ & $S$ & $\mathrm{R}$ & $\mathrm{R}$ & $\mathrm{R}$ & $\mathrm{R}$ & $S$ \\
\hline 9 & $\mathrm{R}$ & $\mathrm{S}$ & $\mathrm{R}$ & $\mathrm{R}$ & $\mathrm{R}$ & $\mathrm{R}$ & $\mathrm{R}$ & $\mathrm{S}$ \\
\hline 10 & $S$ & $S$ & $\mathrm{R}$ & $S$ & $\mathrm{R}$ & $\mathrm{R}$ & $\mathrm{R}$ & $S$ \\
\hline 11 & $S$ & $\mathrm{R}$ & $\mathrm{R}$ & $\mathrm{R}$ & $\mathrm{R}$ & $\mathrm{R}$ & $\mathrm{R}$ & $S$ \\
\hline 12 & $\mathrm{~S}$ & $S$ & $S$ & $\mathrm{R}$ & $\mathrm{R}$ & $\mathrm{R}$ & $\mathrm{R}$ & $S$ \\
\hline 13 & $\mathrm{R}$ & I & $\mathrm{R}$ & $\mathrm{R}$ & $\mathrm{R}$ & $\mathrm{R}$ & $\mathrm{R}$ & $S$ \\
\hline 14 & $\mathrm{R}$ & $S$ & $\mathrm{~S}$ & $\mathrm{R}$ & $\mathrm{R}$ & $\mathrm{R}$ & $\mathrm{R}$ & $S$ \\
\hline 15 & $\mathrm{R}$ & $\mathrm{S}$ & $\mathrm{R}$ & $\mathrm{R}$ & $\mathrm{S}$ & $\mathrm{S}$ & $\mathrm{R}$ & $\mathrm{S}$ \\
\hline Resistance & $40 \%$ & $26 \%$ & $80 \%$ & $60 \%$ & $80 \%$ & $80 \%$ & $86.7 \%$ & $0 \%$ \\
\hline
\end{tabular}

SAM:ampicillin-sulbactam, FEP: Cefepime, NAL: nalidixic acid, CAZ: Ceftazidime, CPD: Cefpodoxime, CXM :Cefuroxim, CRO: Ceftriaxone, NIF: Nitrofurantoin, R: Resistant, S: Sensitive, I: Intermediate according to (CLSI, 2017)

\section{Bioautograph Method}

Flavonoids were selected for our microbiological tests in the presented study using bioautography method. Direct bioautography was performed with E. coli isolate that exhibit good sensitivity to the ethanolic extract of the three plants. TLC plates of ethanolic extract of three plant were prepared in ethyl acetate- methanol-water (100: 13.5: 10) as mobile phase to separate flavonoids. TLC plates were dried for removal of the solvents ${ }^{25}$ and dipped in mixture of MullerHinton (MH) broth and MH agar in the ratio of 90:10 containing bacterial suspension at a concentration of $0.5 \mathrm{McF}$ arland. The TLC plates were then incubated at $37^{\circ} \mathrm{C}$ for $24 \mathrm{~h}$ under humid condition. After $24 \mathrm{~h}$ of 
incubation, tetrazolium salts are used for visualization of microbial growth. These salts are sprayed onto the plates and re-incubated at $37^{\circ} \mathrm{C}$ for $1 \mathrm{~h}$. Clear white zones against a purple background on the TLC plate point to antimicrobial activity of the sample. Then, these zones of inhibition were compared with the RF of the related spots on the reference TLC plate ${ }^{6}$.

\section{RESULTS AND DISCUSSION}

\section{Antibacterial Susceptibility:}

The results of antibacterial susceptibility of $E$. coli isolates against selective antimicrobial agents are listed in Table 1 . The results showed complete sensitivity to nitrofurantoin and prevalence of resistance with different percentage to other different antibiotics ranged from $20 \%$ to $86.67 \%$. The emergence of antimicrobial resistance among uropathogenic $E$. coli is well documented in our country ${ }^{26}$. As the resistance rate to chephalosporine antibiotics group was ranged from $48.5 \%$ to $77.4 \%$ and the nitofurantoin resistance rate was $35.8 \%$.

MIC Assay

Finding healing powers in plants is an ancient idea. With the increasing prevalence of antibiotic resistance, the search for natural alternatives was an imperative to eradicate resistant strains ${ }^{27}$. Table 2 shows the MIC values for the six extracts from the three plants against $E$. coli isolates. The MIC value was determined as the lowest concentration of the extract that inhibiting any bacterial growth and this is detected after adding tetrazolium salts and observed color change.

Table 2: The MIC values for the aqueous and ethanolic extracts from $A$. cyanophylla, $P$. syriaca and $S$. hispanicus against $E$. coli isolates.

\begin{tabular}{ccccccc}
\hline $\begin{array}{c}\text { Isolates } \\
\text { number }\end{array}$ & \multicolumn{2}{c}{ A. cyanophylla } & \multicolumn{2}{c}{ P. syriaca } & \multicolumn{2}{c}{ S. hispanicus } \\
\cline { 2 - 7 } & $\begin{array}{c}\text { Aqueous } \\
\text { mg/mL }\end{array}$ & $\begin{array}{c}\text { Ethanolic } \\
\mathbf{m g} / \mathbf{m L}\end{array}$ & $\begin{array}{c}\text { Aqueous } \\
\mathbf{m g} / \mathbf{m L}\end{array}$ & $\begin{array}{c}\text { Ethanolic } \\
\mathbf{m g} / \mathbf{m L}\end{array}$ & $\begin{array}{c}\text { Aqueous } \\
\mathbf{m g} / \mathbf{m L}\end{array}$ & $\begin{array}{c}\text { Ethanolic } \\
\text { mg/mL }\end{array}$ \\
\hline 1 & 3.125 & 0.190 & 3.125 & 3.125 & 6.25 & 6.25 \\
2 & 12.50 & 0.190 & 6.250 & 3.125 & 12.50 & 12.5 \\
3 & 6.250 & 0.390 & 3.125 & 3.125 & 12.50 & 12.5 \\
4 & 3.125 & 0.390 & 12.50 & 3.125 & 25.00 & 25.0 \\
5 & 6.250 & 0.780 & 6.250 & 6.250 & 25.00 & 25.0 \\
6 & 12.50 & 0.390 & 12.50 & 0.780 & 12.50 & 6.25 \\
7 & 6.250 & 0.780 & 6.250 & 1.560 & 12.50 & 12.5 \\
8 & 12.50 & 3.125 & 12.50 & 6.250 & 25.00 & 25.0 \\
9 & 6.250 & 0.390 & 3.125 & 1.560 & 12.50 & 12.5 \\
10 & 6.250 & 0.780 & 6.250 & 0.780 & 12.50 & 12.5 \\
11 & 6.250 & 3.125 & 12.50 & 1.560 & 25.00 & 25.0 \\
12 & 12.50 & 0.390 & 6.250 & 3.125 & 12.50 & 12.5 \\
13 & 6.250 & 0.780 & 6.250 & 3.125 & 12.50 & 12.5 \\
14 & 3.125 & 0.097 & 6.250 & 6.250 & 12.50 & 12.5 \\
15 & 3.125 & 0.190 & 1.560 & 1.560 & 12.50 & 12.5 \\
\hline
\end{tabular}

In general, the ethanolic extracts were more effective than the aqueous extracts for the same plant. However, the ethanolic A. cyanophylla extract was the most effective against $E$. coli isolates as its MIC values ranged from (0.097 to 3.125) $\mathrm{mg} \backslash \mathrm{mL}$. The aqueous extract MIC values ranged between (3.125 to12.5) mg ImL. The ethanolic extracts of $P$. syriaca activity on $E$. coli isolates started at a concentration of $6.25 \mathrm{mg} / \mathrm{mL}$ for some isolates, while the highest activity was reached at a concentration of $0.78 \mathrm{mg} / \mathrm{mL}$. The aqueous extracts MICs ranged from 12.5 to $3.125 \mathrm{mg} / \mathrm{mL}$ for the studied isolate. Both the ethanolic and aqueous extracts of $S$. hispanicus showed similar efficacy against $E$. coli isolates, where the efficacy ranged between $(25-6.25) \mathrm{mg} / \mathrm{mL}$. The highest antibacterial efficacy of $A$. cyanophylla ethanolic extracts may be is attributed to the richness in phenols and flavonoids, as documented in previous study ${ }^{28}$.

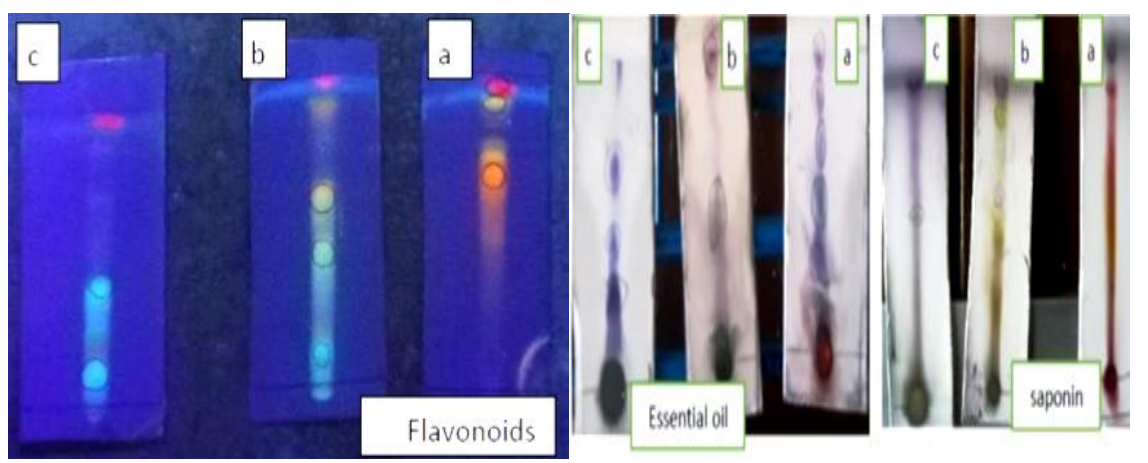

Figure 1: Separated compounds of ethanolic extract of $A$. cyanophylla, $P$. syriaca and $S$. hispanicus aerial part on TLC. 

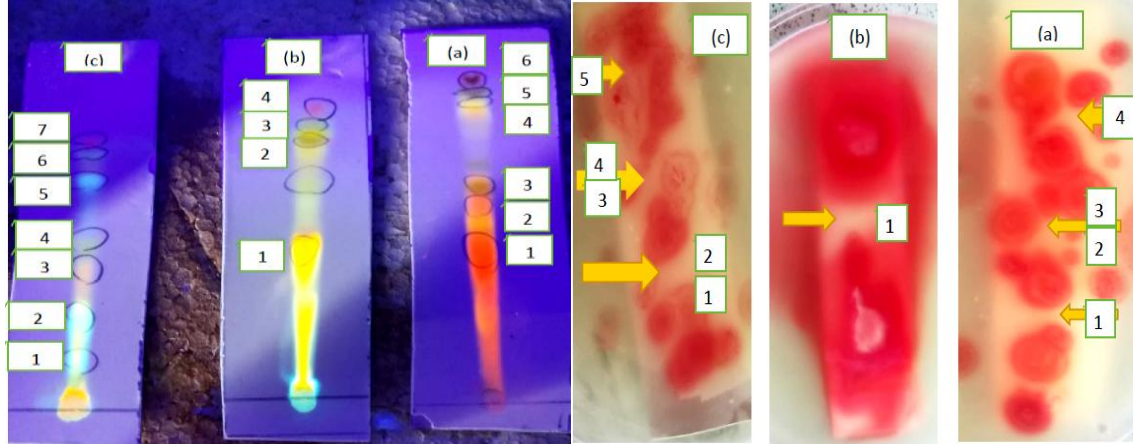

Figure 2: Antibacterial activity of separated flavonoids from ethanolic extracts of (a). A. cyanophylla (b). P. syriaca and (c). S. hispanicus aerial part by bioautography on $E$. coli.

This is in agreement with a (SADIQ et al.,) study on $A$. nilotica where MIC values for Acacia leaf extracts were 1.56 to $3.12 \mathrm{mg} / \mathrm{mL}$, while fruit and bark extracts showed somewhat higher values of 3.12 to $6.25 \mathrm{mg} / \mathrm{mL}$ on E. coli and Salmonella. ${ }^{29}$ It also converges with (Marmouzi et al.,) study, where S. hispanicus extract was tested against five types of bacteria (E. Coli, $S$. aureus, B. subtilus, $S$. enteric and $P$. aeruginosa), and the results showed that $S$. hispanicus roots had the strongest antibacterial activity against $E$. coli bacteria at MIC value of $1.56 \mathrm{mg} / \mathrm{mL}^{30}$.These differences in values can be accounted for the fact that the flavonoids and phenols content are affected by different factors such as place and time of harvest, geographical conditions, climate, time and procedure of extraction, solubility and degree maturation of the plant ${ }^{31}$.

Table 3: Separated compounds of ethanolic extract of $A$. cyanophylla, P.syriaca and $S$. hispanicus aerial part on TLC and their $\mathbf{R}_{\mathrm{F}}$ values.

\begin{tabular}{lccc}
\hline $\begin{array}{l}\text { Ethanolic } \\
\text { plant extract }\end{array}$ & Spots & UV/NP/PEG & Rf values \\
\hline Acacia & 1 & Red & 0.42 \\
cyanophylla & 2 & Orange & 0.55 \\
& 3 & Green & 0.6 \\
& 4 & Yellow & 0.83 \\
& 5 & Green & 0.88 \\
& 6 & Red & 0.92 \\
\hline Phlomis & 1 & Yellow & 0.48 \\
syriaca & 2 & Green & 0.85 \\
& 3 & Blue & 0.9 \\
& 4 & Red & 0.96 \\
\hline S. hispanicus & 1 & Blue & 0.16 \\
& 2 & Blue & 0.3 \\
& 3 & Orange & 0.48 \\
& 4 & Green & 0.58 \\
& 5 & Blue & 0.78 \\
& 6 & Blue & 0.86 \\
& 7 & Red & 0.92 \\
\hline
\end{tabular}

\section{Thin Layer Chromatography (TLC)}

Qualitative phytochemical screening is a basic step to prove presence of particular secondary metabolites in the plant extract of clinical significance. The presence of any important bioactive natural product indicates the necessity of separation of the compounds through appropriate chromatographic techniques ${ }^{32}$. In the present study, the all extracts were checked by thin layer chromatography. the Greenish and orange florescent spots observed after spraying withNP-PEG indicates the presence of flavonoids whereas a violet bluish spots after spraying with vanillin-sulphuric acid and heating indicates bitter principles, saponins and essential oils presence. Red-brown spots were observed using dragendorff reagent indicates the presence of alkaloids ${ }^{24}$. Hence, it has been proven that the three plants contain variable classes of bioactive compounds such like flavonoids, saponin, bitter principles and essential oils. Alkaloids were present in A. cyanophylla while it was absent in $P$. syriaca and $S$. hispanicus (Figure 1). These results are in agreement with the literature review on the studied plants ${ }^{11,15-18}$. These constituents are responsible for various pharmacological properties as antibacterial and antioxidants ${ }^{12,15-17}$

Detection of antibacterial activity by Bioautography The chromatograms of ethanolic extract of three plants were developed in order to calculate $\mathrm{Rf}$ values of the spots Table 3 and Figure 1. Table 2 showed that the three plants showed several flavonoids spots of different colors after spraying with the NP/PEG reagent where it was observed with $A$. cyanophylla six spots of different colors with $\mathrm{Rf}$ values $0.42,0.55,0.6,0.83$, $0.88,0.92$, respectively. While it appeared with $P$. syriaca, four color spots with $\mathrm{Rf}$ values 0.48 , 0.85, $0.90,0.96$, respectively. Also featured with $S$. hispanicus are seven spots in different colors with RF values $0.16,0.30,0.48,0.58,0.78,0.86,0.92)$, 
respectively. Previous studies indicate that when the fluorescence appears orange- yellow colors, the compound may be flavonols while yellow-green fluorescence indicates possible presence Kaempferol, isorhamnetin and their glycosides and apigenin and their glycosides ${ }^{33}$. Also the appearance of fluorescence orange indicates the possibility of presence flavones such as Luteolin and their glycosides ${ }^{33}$. After spraying with tetrazolium salts, the antibacterial activity of some separated flavonoids compounds were revealed as yellow inhibition zones around $E$. coli Figure 2.

Figure 2 shows that the antibacterial activity with $A$. cyanophylla was shown in spots $(1,2,3,4)$ with $\mathrm{R}_{\mathrm{f}}$ values of $0.42,0.55,0.6,0.83$, While in $P$. syriaca it appeared in only one spot (1) with $\mathrm{R}_{\mathrm{f}}$ values (0.48) and in $S$. hispanicus, the anti-bacterial activity appeared in the spots $1,2,3,4,5$ with $\mathrm{R}_{\mathrm{f}}$ values of $0.16,0.3,0.48$, $0.58,0.87$.This is consistent with previous studies where it was found in vitro that the antibacterial activity of flavonoids it can be practiced in three ways: direct and synergistic killing of bacteria the antibiotics activate and weaken the bacteria pathogenicity. Also, the flavonoids showed inhibitory activity against the flow pump bacterium, and it restricted peptidogly can synthesis in amoxicillin-resistant $E$. coli. The inhibition activity of different types of lactamases produced by bacteria by flavonoids was also documented ${ }^{3}$. It was found that A. cyanophylla, $P$. syriaca and $S$. hispanicus have a total phenolic content in ethanolic extract of aerial part reached to $98.39,46.73,14.48 \mathrm{mg}$ GAE g/g extract respectively and total flavonoids contents reached to $121.64,52.49,35.59 \mathrm{mg}$ of $\mathrm{RE} / \mathrm{g}$ extract respectively ${ }^{28}$, Which reflects the antibacterial activity of these plants.

\section{CONCLUSION}

In this study, TLC results showed that the three plants contain flavonoids, saponins, bitter principles and essential oils. The ethanolic extract of A. cyanophylla has strong antibacterial activity against $E$. coli compared to the other two studied plants, as MIC values were ranged 0.097 to $3.125 \mathrm{mg} / \mathrm{ml}$. The results indicate that most flavonoids in the ethanolic extract of the three plants have antibacterial activity, as shown by the direct Bioautography technique

\section{AUTHOR'S CONTRIBUTION}

All authors analyzed the data, wrote the manuscript and reviewed it.

\section{ACKNOWLEDGEMENTS}

The authors extend their thanks and appreciation to the Faculty of Pharmacy, University of Aleppo, Syria to provide necessary facilities for this work.

\section{CONFLICT OF INTEREST}

The authors declare no conflict of interest.

\section{REFERENCES}

1. Sasidharan S, Chen Y, Saravanan D, Sundram KM, Latha LY. Extraction, isolation and characterization of bioactive compounds from plants' extracts. African J Trad, Comp Alt Med 2011; 8(1): 1-10. PMID: 22238476

2. Gebreyohannes G, Nyerere A, Bii C, Sbhatu DB. Determination of antimicrobial activity of extracts of indigenous wild mushrooms against pathogenic organisms. Evidence-based Comp Alt Med, 2019. https://doi.org/10.1155/2019/6212673

3. Xie Y, Yang W, Tang F, Chen X, Ren L. Antibacterial activities of flavonoids: Structure-Activity Relationship and mechanism. Cur Med Chem 2015;(22): 132-149 https://doi.org/10.2174/0929867321666140916113443

4. Chibane LB, Forquet V, Lantéri P, et al. Antibacterial properties of polyphenols: characterization and QSAR (Quantitative Structure-Activity Relationship) models. Front Microbiol 2019;(10): 829. https://doi.org/10.3389/fmicb.2019.00829

5. Jesionek W, Grzelak EM, Dziedzic BM, Choma IM. Thinlayer chromatography - direct bioautography for the screening of antimicrobial properties of plant extracts. J Planar Chromat - Modern TLC 2013; 2(26): 109-113.

6. Dewanjee S, Gangopadhyay M, Bhattacharya N, Khanra R, Dua TK. bioautography and its scope in the field of natural product chemistry. J Pharm Anal 2015; 5(2):75-84. https://doi.org/10.1016/j.jpha.2014.07.001

7. Choma IM, Grzelak EM. Bioautography Detection In Thin-Layer Chromatography. J Chrom A 2011; (1218): 2684-2691.https://doi.org/10.1016/j.chroma.2010.12.069

8. Sufi Da, Sunday E, Mustapha T. Antibacterial effect of Acacia Nilotica and Acacia Senegalensis fruit extracts on Escherichia Coli and Salmonella Typhi. FUTY J Environ 2020; (2)14. PMID: 24266104

9. Kayali R, Kitaz A, Haroun M. Antibacterial activity of Asphodelin Lutea and Asphodelus microcarpus against methicillin resistant Staphylococcus Aureus Isolates. Int J Pharmacog Phytochem Res 2016; 8(12): 1964-1968. https://doi.org/10.9734/BBJ/2016/20505

10. Maroyi A. Acacia karroo Hayne: Ethnomedicinal uses, phytochemistry and pharmacology of an important medicinal plant in southern Africa. Asian Pacific J Trop Med 2017; 10(4): 351-360. https://doi.org/10.1016/j.apjtm.2017.03.021

11. Abbasian K, Asgarpanah J, Ziarati P. Chemical composition profile of Acacia nilotica seed growing wild in south of Iran. Oriental J Chem 2015; 31(2):1027-1033. https://doi.org/10.13005/ojc/310251

12. Noreen I, Iqbal A, Rabbi F, Muhammad A, Shah Z, Rahman ZU. Antimicrobial activity of different solvent extract of Acacia Cyanophylla. Pakistan J Weed Sci Res 2017; 23(1): 79-90,

13. Ghribia L, Ghouilaa H, Omrib A, Besbesb M, Janneta HB. Antioxidant and anti-acetylcholinesterase activities of extracts and secondary metabolites from Acacia cyanophylla. Asian Pac J Trop Biomed 2014; 4(1): 417423. https://doi.org/10.12980/APJTB.4.2014C1038

14. Firdous S, Ahmed H, Hussain M, Shah M. Pollen morphology of Ajugal l., Lamium 1. and phlomis 1. (lamiaceae) from district abbott abad pakistan. Pakistan $\mathrm{J}$ Bot 2015; 47(1): 269-274. https://doi.org/10.19045/bspab.2015.44003

15. Al-Qudah MA, Obeidat SM, Saleh AM, El-Oqlah AA, AlMasaeed E, Al-Jaber HI. Volatile components analysis, total phenolic, flavonoid contents, and antioxidant activity of Phlomis species collected from Jordan. J Essen Oil Bearing Plant 2018; 21(3): 583-599. https://doi.org/10.1080/0972060X.2018.1489739

16. Polo S, Tardío J, Burgo AV, Molina M, Santayana MP. Knowledge, use and ecology of golden thistle (Scolymus hispanicus L.) in Central Spain. J Ethnobiol Ethnomed 2009; 5:42. https://doi.org/10.1186/1746-4269-5-42 
17. Altiner DD, Sahan Y, A functional food additive: Scolymus Hispanicus L. Flour. Int J Food Eng 2016; 2(2): 124-127. https://doi.org/10.18178/ijfe.2.2.124-127

18. Ahmad B. Extraction of phytochemicals from Scolymus hispanicus and determination of potential health effects. Thesis, Master of Science in Biotechnology, Izmir Institute, Turkey 2017; 76.

19. Meena RK, Ansari K, Kishor N, Chouhan N. Green synthesis of silver nanoparticles using Acacia concinna plant extract and their antibacterial activity. Res J Recent Sci 2018; 7(3): 1-6.

20. Sahraoui R, Djellali S, Chaker AN. Morphological, anatomical, secondary metabolites investigation and physicochemical analysis of Cistus creticus. Pharmacog Comm 2013; 4(3): 58-63.

https://doi.org/10.5530/pc.2013.4.8

21. Stanković MS. Total phenolic content, flavonoid concentration and antioxidant activity of Marrubium peregrinu extracts. Kragujevac J Sci 2011; 33: 63-72. https://doi.org/10.3390\%2Fplants 8040096

22. Wayne Pa. CLSI, Performance standards for antimicrobial susceptibility testing. $27^{\text {th }}$ ed CLSI supplement M100. Clinical and Laboratory Standards Institute 2017:240.

23. AdamczakA, OżarowskiM, Karpiński TM. Antibacterial activity of some flavonoids and organic acids widely distributed in plants. J Clin Med 2020; 9(1): 109. https://doi.org/10.3390/jcm9010109

24. Wagner H, Bladt S, Zgainski EM. Plant Drug analysis, a thin layer chromatography atlas. $1^{\text {st }}$ ed., Springer-verlag Berlin Heidelberg, Germany; 1984:314. https://doi.org/10.1007/978-3-642-00574-9

25. Masoko P, Gololo SS, Mokgotho MP, Eloff JN, Howard RL, Mampuru LJ. Evaluation of the antioxidant, antibacterial, and antiproliferative activities of the acetone extract of the roots of Senna italica (Fabaceae). African J Trad Comp Alt Med 2010; 7(2): 138-148. https://doi.org/10.4314/ajtcam.v7i2.50873

26. Al-kayali R. Study of biofilm formation in clinical bacterial isolates of rinary tract infection. Tishreen Univ J Med Sci Ser 2017;39(3):220-227. https://doi.org/10.1016/j.micpath.2017.05.014

27. Ciocan ID, Băra II. Plant Products as antimicrobial agents. Clin Microbiol Rev J1999; 12(4): 564-582. PMID: 10515903

28. Jalab J, Kitaz A, Abdelwahed W, Kayali R. Green synthesis of silver nanoparticles using some medicinal plants. Int Res J Pure App Chem2020; 21(24): 13-26. https://doi.org/10.9734/irjpac/2020/v21i2430330

29. Sadiq MB, Tarning J, Cho TZA, Anal AK. Antibacterial activities and possible modes of action of Acacia nilotica (1.) Del against multidrug-resistant Escherichia coli and Salmonella. Molecules 2017; 22(1): 47. https://doi.org/10.3390/molecules22010047

30. Marmouzi I, Karbane M, Hamdani M, et al. Phytochemical and pharmacological variability in golden thistle functional parts: comparative study of roots, stems, leaves and flowers. Nat Prod Res 2017; 31(22): 2669-2674. https://doi.org/10.1080/14786419.2017.1283494

31. Rajhi I, Ben Dhia MT, Abderrabba M, Ouzari-Hadda I, Ayadi S. Phytochemical screening, in vitro antioxidant and antibacterial activities of methanolic extracts of Capparis spionsa 1 different parts from Tunisia. J Mat Env Sci 2019; 10(3): 234-243.

32. Sharif S, Kitaz A, Al-Kayali R. TLC Screening and evaluation of antioxidant, antibacterial activity of Onopordon macrocephalum by bioautography method. Iranian J Pharm Sci 2016; 12(2): 1-8.

33. Debenedetti SL. TLC and PC in isolation, identification and characterization of allelochemicals. In: Vattuone MA, Catalán CA, Sampietro DA, editors. Textbook of Isolation, Identification and Characterization of Allelochemicals, CRC Press; 2009:103-133. 